Int. J. Dev. Biol. 58: 403-411 (2014)

doi: $10.1387 / \mathrm{ijdb} .140125 \mathrm{nr}$

\title{
Establishing the germline in spiralian embyos
}

\author{
NICOLE REBSCHER* \\ Morphology and Evolution of Invertebrates, Phillips Universität Marburg, Marburg, Germany
}

\begin{abstract}
Elucidating the origin of germ cells in embryos and larvae is often obscured by the fact that the typical germ cell markers vasa, nanos and piwi are not exclusively expressed in primordial germ cells (PGCs), but are also commonly found in undifferentiated somatic tissues and stem cells as part of an evolutionary conserved 'germline multipotency program' (Juliano et al., 2010). Hidden in the crowd of undifferentiated cells, the PGCs have occasionally been overlooked and their formation during early embryogenesis was only revealed recently by new methodological approaches (e.g.Wu et al., 2011). Spiralians are excellent model organisms to deepen our understanding of PGC formation, given the highly stereotypical cleavage that occurs during embryogenesis. In these species, detailed cell lineage studies enable the tracing of single cells up to gastrulation stages. Here, I review our knowledge of the origin of PGCs in these invertebrates. Similarities in PGC formation among spiralian phyla as well as peculiarities of the highly derived clitellates are discussed with respect to developmental mode and evolution. Furthermore, the issue of gonad regeneration in platyhelminths and the asexually reproducing oligochaete Enchytraeus japonensis is addressed. An alternative strategy of compensating for caudal regeneration is presented for the polychaete Platynereis dumerilli. Finally, the molecular bases of PGC specification and the question of germplasm are discussed.
\end{abstract}

KEY WORDS: Spiralia, primordial germ cell, mesoblast, vasa, nanos, PIWI

\section{Introduction}

Sexual reproduction and thus the acquisition of new traits require heterozygous gametes, which arise by meiosis from oogonia or spermatogonia during gametogenesis. Gonia are descendants of the 'primordial germ cells' (PGCs), which in turn form during embryonic development by asymmetric cleavage from multipotent cells called 'presumptive primordial germ cells' (pPGCs). While the pPGCs contribute to both soma and germline, the PGCs are the first cells of a developing organism exclusively restricted to a germ cell fate (Extavour and Akam, 2003; Nieuwkoop and Satasurya, 1979; Wylie 1999). Following their formation, the PGCs often become transcriptionally and mitotically quiescent and migrate actively towards the developing somatic gonads (Seydoux \& Brown 2006). In many species exhibiting a constant production of gametes, such as Drosophila, C. elegans, or the mouse, the PGCs transform into so called germ cell stem cells (GSCs), once they reach a special 'niche' in the gonad. Signaling molecules control the constant stem cell-like asymmetric divisions of the GSCs, with one daughter cell entering gametogenesis, while the other one maintains stem cell characteristics (Spradling et al.,2001). In species exhibiting high regenerative capacities or asexual reproduction, stem cells with dual germline and somatic potential exist transiently or even lifelong, such as in planarians, the trematode Schistosoma mansoni, the oligochaete Enchytraeus japonensis or the colonial ascidian Botryllus primigenus. These cells are referred to as 'germline cell stem cells', 'germinal cells', 'prePGCs' or 'primordial stem cells' by different authors, in contrast to true PGCs, which are committed exclusively to the germline, or their direct precursors, the asymmetrically dividing pPGCs (Kato et al.2013; Shibata et al.,2010; Solana, 2013; Sugio et al.,2008; Wang et al.,2013).

The segregation of the germline from the somatic lineage occurs at different time points in development, which vary greatly among species: in Drosophila, the PGCs are the first to cellularize after fertilization (Huettner, 1923). Similarly, the single germline progenitor P4 in C. elegans arises already at the fourth cleavage of the embryo (Seydoux and Fire, 1994). In many deuterostome and lophotrochozoan phyla, the PGCs are specified during blastula or gastrula stages, such as in the sea urchin Stronglocentrotus purpuratus, the ascidian Ciona intestinalis, the cephalochordate Branchiostoma floridae, the vertebrates Danio rerio, Gallus gal-

Abbreviations used in this paper: dpf, days post fertilization; hpf, hours post fertilization; M, mesoblast; PGC, primordial germ cell.

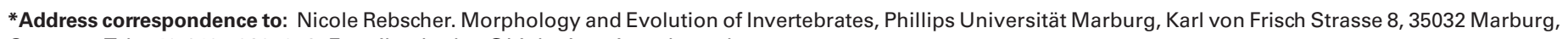
Germany.Tel: +49-6421-2825958. E-mail: rebscher@biologie.uni-marburg.de
}

Accepted: 18 September 2014.

ISSN: Online 1696-3547, Print 0214-6282 
Ius, Xenopus laevis, Mus musculus, as well as in the polychaete Platynereis dumeriliiand the gastropod Crepidula fornicata (Lyons et al.,2012; Raz, McLaren, 2003; 2002; Rebscher et al.,2012; Shirae-Kurabayashi et al.,2011; Taguchi et al.,2012; Tsunekawa et al.,2000; Wu et al.,2011; Yajima and Wessel, 2011a). In species exhibiting high regenerative capacities, such as cnidarians and platyhelminths, the potential to develop PGCs from stem cells even is maintained lifelong (Mochizuki et al.,2001; Peter et al.,2004; Rink, 2013).

Two distinct mechanisms of PGC specification exist in the animal kingdom: in Drosophila, C. elegans, or Xenopus laevis, the future PGCs inherit germ plasm containing maternal determinants early in development (Ikenishi et al.,1986; Mahowald, 2001; Strome and Wood, 1982). Alternatively, the PGCs are specified from undifferentiated cells by inductive signals, as it has been described from such diverse species as the cnidarian Nematostella and the mouse (Extavour et al.,2005; Tsang et al.,2001). Examples for both mechanisms can be found throughout the animal kingdom, but the

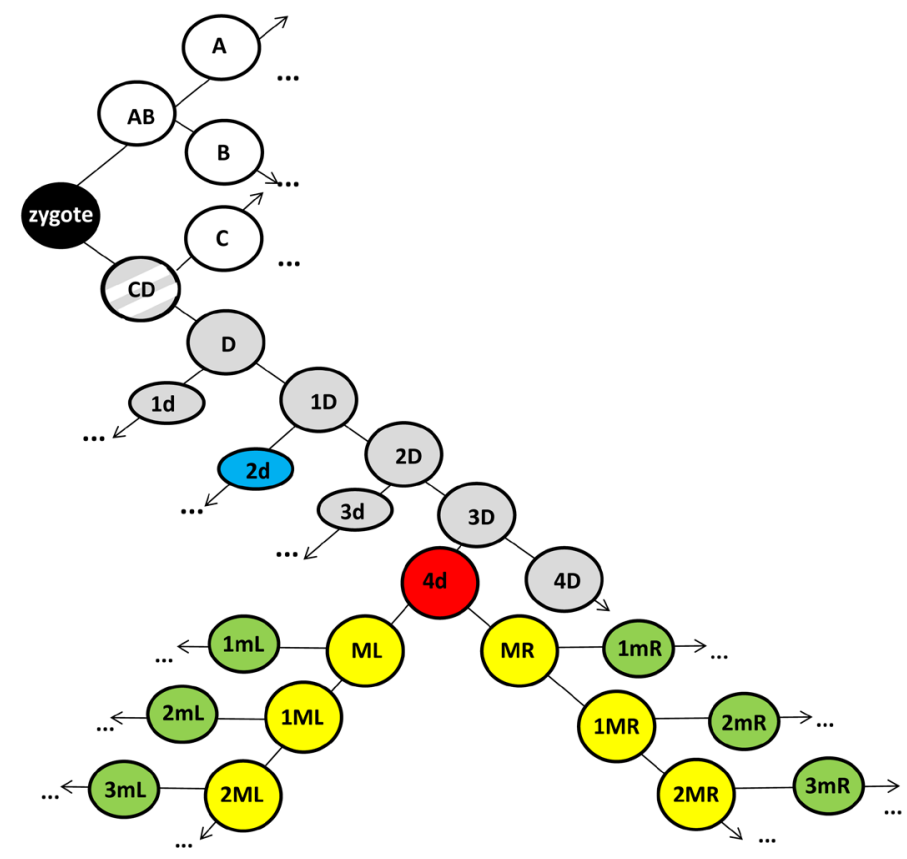

Fig. 1. Generalized cell-lineage of the D-quadrant in spiralian embryos. The zygote (black) divides twice, yielding four large blastomeres; the macromeres A-D (white and grey), corresponding to the four quadrants of the embryos. For simplification, only the fate of the D-quadrant (grey) is shown from here on. The $D$-macromere bud of generations of micromeres called $1 d, 2 d, 3 d . .$. (grey) towards the animal pole during spiral cleavage. The micromeres continue dividing in animal/vegetal orientation (not shown), with exception of the somatoblast $2 d$ (b/ue) and the mesoblast $4 d$ (red), which both divide bilaterally, forming the precursors of trunk ectoderm and mesoderm, respectively. The $4 d$-micromere divides bilaterally into the left and right mesoblast (MR and ML, yellow). The mesoblasts in turn produce small blast cells (green) named $1 m, 2 m, 3 m \ldots$ according to their birth rank, while they maintain their stem cell characteristics (1M, 2M, 3M...). The mesodermal blast cells are the founders of diverse cell types and tissues, such as the primordial germ cells, the mesodermal posterior growth zone, the trunk mesoderm and other structures (see in text). Blastomere nomenclature according to Lyons et al.2012. Cell lineage modified after (Fischer and Arendt, 2013; Lyons et al.,2012; Rebscheret al.,2012; Schneider and Bowerman, 2007). latter mechanism, sometimes referred to as 'epigenesis', has been proposed to constitute the ancestral mode of PGC specification in metazoans (Extavour and Akam, 2003). This assumption is supported by the finding that the PGCs often become detectable only late in development within undifferentiated tissue expressing the typical germ cell markers vasa, nanos and piwi (reviewed in Extavour and Akam, 2003). Experimental evidences for specific inductive cues such as BMP2/4, as well as a demonstration of the full totipotency of their putative founder cells however are so far restricted to few species, i.e. mouse, axolotl and the cricket Gryllus bimaculatus (Donoughe et al., 2014; Johnson et al.,2003; Ying et al.,2001). Recently, the hypothesis of an evolutionary ancestry of late PGC specification by inductive signals has been challenged by the use of additional molecular markers as well as new methodological approaches including transgenic lines, lineage tracing, live imaging, and EdU pulse/chase experiments, which allows for the identification of PGCs at much earlier stages (Fischer and Arendt, 2013; Lyons et al.,2012; Raz, 2002; Rebscher et al.,2012). It became evident by these studies, that in some species, vasa, nanos and piwi expressing cells do not form a homogeneous population of undifferentiated cells, from which the PGCs are specified by inductive signals, but rather constitute a mix of PGCs and undifferentiated somatic cells. In the cephalochordate Branchiostoma floridae for example, the PGCs were previously assumed to emerge late in development from the growth zone (Nieuwkoop and Satasurya, 1979). Recently however, it has been shown that the first two PGCs are already detectable at the onset of gastrulation, while the nanos, piwi, and vasa expressing cells of the posterior growths zone form later around the transition from mid- to late gastrula stages (Wu et al.2011). During neurulation, the PGCs merge with the growth zone, and are indistinguishable from it until larval stages. Similarly, the PGCs of the polychaete Platynereis dumerilli are initially indistinguishable from the cells of the mesodermal posterior growth zone by both morphology and gene expression pattern. However, they arise several hours earlier in development and are mitotically quiescent, in contrast to the proliferating somatic stem cells (Rebscher et al.,2012). Putative PGCs forming a subpopulation within larger clusters of vasa expressing cells are also found in the gastropod Haliotis asinina (Kranz et al.,2010). In the platyhelminths Dugesia japonica, Schmidtea mediterraneaand Schistosoma mansoni, the expression of the germ cell marker nanos is limited to a subpopulation within the piwi/argonaute-positive neoblasts (Handberg-Thorsager and Saló, 2007; Sato et al.,2006; Shibata etal.,2010; Wang et al.,2013).

Taken together, the presence of PGCs as a distinct subpopulation within vasa, nanos, and piwi positive cells indicates, that the PGCs not necessarily arise rise from these stem cells during ontogenesis. Rather, the co-expression of these genes might be explained by the common ontogenetic and evolutionary origin of these two cell types, which is reflected by a conserved molecular 'germline multipotency program' (Gazave et al.,2013; Juliano et al.,2010; Seydoux and Strome, 1999).

A second obstacle when investigating the origin of the germ cells is the reliance on maternal vasa, nanos, and piwi transcripts as germ cell markers. These mRNAs are found broadly distributed in embryos of many species as maternal transcripts, and only the zygotic transcripts can be considered to be truly germ cell-specific (Lasko, 2011; Pilon and Weisblat, 1997 Rebscher et al.,2007; Shinomiya et al.,2000). Maternal transcripts might be furthermore be 
initially subject to translational repression (Vasudevan et al.2006), while PGC specification might be mediated in the meantime by maternal proteins. Focusing on the analysis of maternal transcripts alone may therefore provoke misleading conclusions regarding the timing and mode of PGCs specification in some species. Unfortunately, specific antibodies allowing the detection of these proteins are often not available in non-model organisms. Therefore the localization of these proteins in early forming PGCs, hidden between vasa, nanos, and piwi expressing somatic cells, might have been overlooked.

Taken together, increasing evidence suggests that the PGCs might be specified early in more species than previously expected, with maternal proteins orchestrating this process. In the absence of specific antibodies for early PGCs, lineage analysis is a powerful tool to address this question in depth. The highly stereotypical cleavage pattern of spiralian embryos (Lambert, 2010) renders them perfect model organisms for the investigation of the origin of the PGCs. Here, I will review the current knowledge on PGC formation in this interesting, yet so far rarely investigated group of invertebrates.

\section{Origin of the germ cells in spiralian embryos}

Cell lineage has been studied extensively in spiralian embryos: at the end of the $19^{\text {th }}$ century pioneering studies were conducted in the gastropod Crepidula fornicata (Conklin, 1897), as well as in the polychaetes Nereis limbata (succinea) and Platynereis megalops (Wilson, 1892). Spiralians share a highly conserved early cleavage pattern and fate map (Gline et al.,2011; Henry and Martindale, 1998; Lambert, 2010). A common feature is the formation of the large micromere $4 \mathrm{~d}$ (also called $\mathrm{M}$ in Nereis spp. or DM in the leech), which occurs by asymmetric cleavage during the $6^{\text {th }}$ cleavage round (Fig. 1 and Fischer and Arendt, 2013; Gline et al.,2011). This blastomere then divides bilaterally, yielding a pair of stem cells called mesoblasts or mesoteloblasts, respectively, depending on their size. In some spiralians, the 4d descendants additionally contribute to ectodermal and endodermal tissue, and are therefore occasionally referred to as mesectoblasts or mesendoblasts, respectively. The paired mesoblasts have previously been addressed by various names in different species such as MR/L in the leeches Helobdella austsinensis, and H. robusta, M1/2 in Nereis spp., 4d $\mathrm{d}^{1 / 2}$ in Platynereis, $4 \mathrm{dR} / \mathrm{L}$ in Crepidula, and $\mathrm{Mr} / \mathrm{l}$ in Ilyanassa obsoleta(Dorresteijn, 1990;Ackermann etal.,2005; Henry et al.,2010; Lambert, 2010; Wilson, 1892). However, a uniform spiralian nomenclature was recently devised (Lyons et al.,2012) and will be used throughout this review in order to facilitate cross species comparisons.

The right and left mesoblasts MR/L undergo asymmetrical stem-cell-like divisions, producing small, undifferentiated cells called 'blast cells'. While in the course of this review, only the mesodermal blast cells are discussed, it has to be pointed out the 'blast cells' also occur in other lineages e.g. in the clitellates (Weisblat and Shankland, 1985). The blast cells are numbered $1 \mathrm{mR} / \mathrm{L}, 2 \mathrm{mR} / \mathrm{L}$ and so on, according to their birth rank (Fischer and Arendt, 2013; Gline et al.,2011; Lyons et al.,2012 and Fig. 1). In clitellates, the blast cells are exclusively produced towards the anterior pole of the developing worm, forming regular, elongating germbands (Gline et al.,2011; Weisblat and Shankland, 1985). Instead, the blasts cells of the gastropods Crepidula fornicata and
Ilyanassa obsoleta are budded off in alternating directions, thus forming a blast cell cluster with the mesoblasts lying in the center (Lyons et al.,2012; Rabinowitz et al.,2008; Swartz et al.,2008). In the trochophore larva of the polychaete Platynereis dumerilii, the blast cells also form a cluster, but since they bud forth in an anterior direction only, the cluster lays anterior of the mesoblasts (Fischer and Arendt, 2013; Rebscher et al.,2012).

In most spiralian species, for which cell lineage has been analyzed to this level, the blast cells or their descendants, respectively, are the source of the PGCs (Cho et al.,2013; Fischer and Arendt, 2013; Kato et al.,2013; Kranz et al.,2010; Lyons et al.,2012; Rebscher et al.,2012; Schneider and Bowerman, 2007; Wilson, 1892 and Table 1). In the bivalve Sphaerium striatinum instead, the mesoblasts themselves have been proposed to cease dividing after 3 rounds of asymmetric cleavage and to develop into a pair
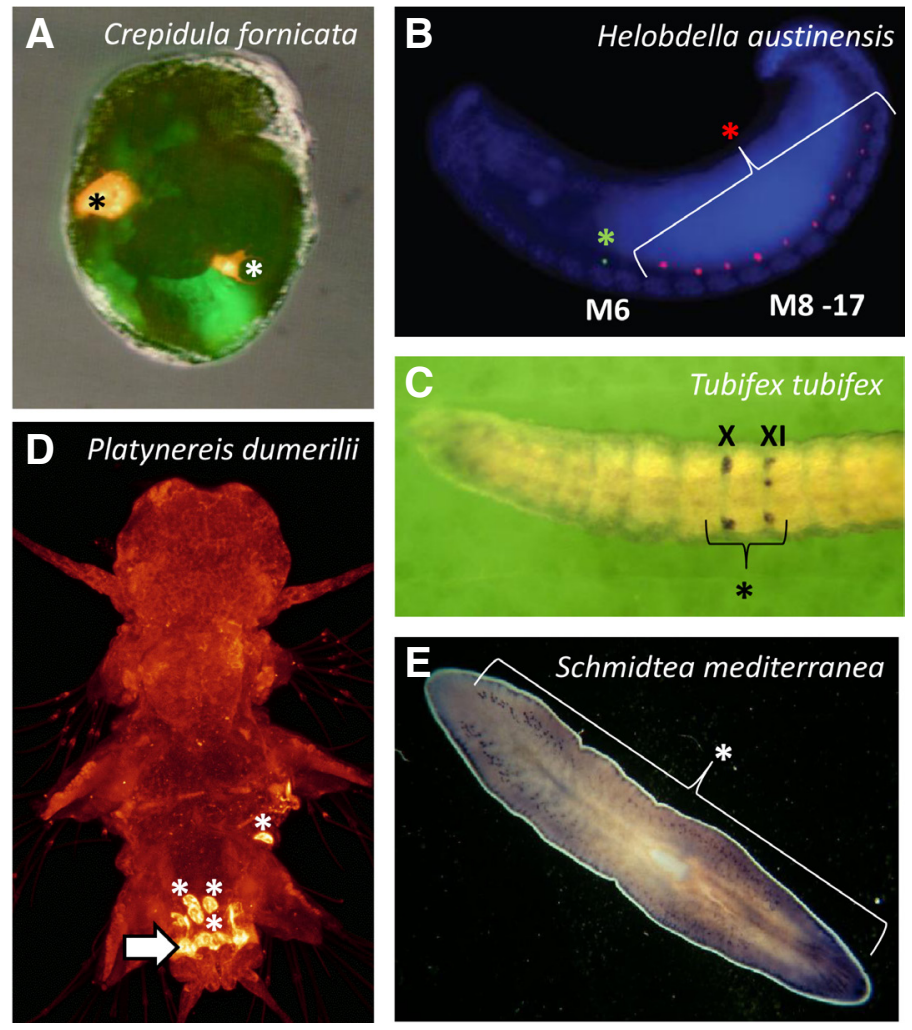

Fig. 2. Location of primordial germ cells (PGCs) in spiralian larvae and juveniles. (A) In the gastropod Crepidula fornicata, the right PGC (white asterisk) is labelled upon injection into the blast cell $2 m R^{2}$ in this veliger larva, lateral view. The crystal cell (black asterisk), a somatic descendant of $2 m R^{2}$, is also labelled (image courtesy of Jonathan Henry). (B) Piwi expressing PGCs in the leech Helobdella austinensis in the midbody segments M6 (female genital segment, green asterisk) and M8 - 17 (future male genital segments, red asterisks) in a stage 10 juvenile. Nanos expression (red) is lacking in the future oogonia (image modified after Cho et al.2013 with permission from MBE). (C) Vasa positive PGCs (black asterisks) in the future female (X) and male (XI) genital segments of Tubifex tubifex (image by Takashi Shimizu, with permission from the author). (D) Four single PGCS (white asterisks) leaving the mesodermal posterior growth zone (arrow) in a Platynereis dumerilii three segmented young worm. Immunohistochemical detection of Vasa protein. (E) Nanos expressing PGCs (white asterisks) in the location of the future testes in the planarian Schmidtea mediterranea (image courtesy of Emili Saló). 


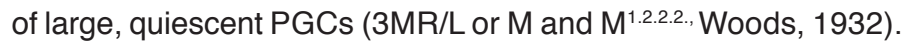
Similarly, Swartz et al.2008 suggested, that the corresponding cells in the gastropod Ilyanassa (here called $4 \mathrm{dR} / \mathrm{L}^{121}$ ) might constitute the founders of the germline based on their prolonged vasa expression. However, the latter authors do not rule out that vasa expression in the mesoblasts might rather reflect a function in the somatic lineage. Being more in line with the notion, that generally the blast cells are the founders of the germline in spiralians, the Ilyanassa Nanos protein has been found to persist longest in the nuclei of the blast cells $2 \mathrm{mR} / \mathrm{L}^{2}$ (here called $4 \mathrm{dL}$ / $\mathrm{R}^{112}$, Rabinowitz et al.,2008), which are homologous to the direct PGC precursors in the gastropod Crepidula (Lyons et al.2012). In the current absence of markers for PGCs in mollusk larvae, the identity of the PGCs in Ilyanassa and Sphaerium cannot be unambiguously answered at the moment. Modern lineage tracing methods or the use of species-specific Vasa antibodies in larval stages and beyond would be suitable approaches to address this open question.

In the nemertean Cerebratulus lacteus, the planarian Hoploplana inquilina, the sipunculan Phascolosoma esculenta and the myzostomid Myzostoma cirriferum, current cell lineage studies unfortunately do not extend beyond $4 d$, therefore the precise origin of their germline remain to be elucidated (Boyer et al.,1998;
Henry and Martindale, 1998; Weigert et al.,2013; Ying et al.,2009 and Table 1).

In clitellates, the PGCs form directly at the site of the future gonads in their respective segments (Cho et al.,2013; Kato et al.,2013 and Fig. 2). Similarly, nanos expressing putative male germ cells are first detectable at the location of the future testes in the planarian Schmidtea mediterranea (Handberg-Thorsager and Saló, 2007 and Fig. 2). In the oyster Crassostrea gigas, the gastropod Haliotis asinina or the polychate Capitella telata, the PGCs initially form transient, bilateral clusters in the trunk region of the larvae (Dill and Seaver, 2008; Kranz et al.,2010; Fabioux et al.,2004 and Fig. 2). In other species, such as in the mollusks Crepidula fornicata and Sphaerium striatinum or the polychaete Platynereis dumerilii, the PGCs reside in the larval mesoderm as single cells (Lyons et al.,2012; Rebscher et al.,2007; Woods, 1931 and Fig. 2). In Platynereis dumerilii, the four PGCs migrate actively as single cells from the posterior growth zone along the mesoderm towards the neck region of the larva, which acts as a transient gonad (Rebscher et al.,2007). PGCs migration most likely also occurs in the polychaete Capitella telata (Giani et al.,2011). Whether active migration of PGCs occurs in other spiralian species as well, or whether the PGCs are rather passively transported during gastrulation movements, so far remains

TABLE 1

\section{ORIGIN OF PRIMORDIAL GERM CELLS IN SPIRALIAN EMBRYOS}

\begin{tabular}{|c|c|c|c|c|c|c|}
\hline Phylum/Class & Species & Un-known & Proposed 4d origin & $4 d$ origin & PGC identity & References \\
\hline \multicolumn{7}{|l|}{ Annelida* $^{*}$} \\
\hline \multirow[t]{3}{*}{ Clitellata } & Enchytraeus japonensis & $\mathbf{x}$ & & & & $\begin{array}{l}\text { Sugio et al. } 2008 \\
\text { Tadokoro et al. } 2008\end{array}$ \\
\hline & Helobdella spp. ${ }^{* *}$ & & & $x^{t p l}$ & $\begin{array}{c}16 \mathrm{mR} / \mathrm{L} \\
18-23 \mathrm{mR} / \mathrm{L}\end{array}$ & $\begin{array}{l}\text { Kang et al. } 2002 \\
\text { Cho et al. } 2013\end{array}$ \\
\hline & Tubifex tubifex & & & $x^{t p l}$ & $\begin{array}{l}10 \mathrm{mR} / \mathrm{L} \\
11 \mathrm{mR} / \mathrm{L}\end{array}$ & $\begin{array}{l}\text { Kato et al. } 2013 \\
\text { Oyama et al., } 2007\end{array}$ \\
\hline \multirow[t]{3}{*}{ 'Polychaeta' } & Capitella telata & & & $x^{t}$ & & $\begin{array}{l}\text { Mayer et al. } 2010 \\
\text { Dill \& Seaver } 2008\end{array}$ \\
\hline & Platynereis dumerilii & & & $x^{t p l}$ & $\begin{array}{l}1 \mathrm{mR} / \mathrm{L} \\
2 \mathrm{mR} / \mathrm{L}\end{array}$ & Rebscher et al. 2012 \\
\hline & Salmacina dysteri & & & $x^{h}$ & $1 \mathrm{mR} / \mathrm{L}$ & Malaquin 1925 \\
\hline Myzostomida & Myzostoma cirriferum & $\mathbf{x}$ & & & & Weigert et al. 2013 \\
\hline Sipunculida & Phascolosoma esculenta & $\mathbf{x}$ & & & & Ying et al. 2009 \\
\hline \multicolumn{7}{|l|}{ Mollusca } \\
\hline \multirow[t]{2}{*}{ Bivalvia } & Crassostrea gigas & & $x^{t}$ & & & Fabioux 2004 \\
\hline & Sphaerium striatinum & & & $x^{h}$ & $\left(3 \mathrm{MR}_{* *+} / \mathrm{L}\right)$ & Woods 1931 \\
\hline \multirow[t]{3}{*}{ Gastropoda } & Crepidula fornicata & & & $x^{t \prime}$ & $\begin{array}{l}2 m R^{22} \\
2 m L^{22}\end{array}$ & $\begin{array}{l}\text { Lyons et al. } 2012 \\
\text { Henry et al } 2010\end{array}$ \\
\hline & Haliotis asinina & & $x^{t}$ & & & Kranz et al. 2010 \\
\hline & Ilyanassa obsoleta & & & $x^{\mathrm{tpl}}$ & $m$ & $\begin{array}{l}\text { Swartz et al. } 2008 \\
\text { Rabinowitz et al. } 2008\end{array}$ \\
\hline \multicolumn{7}{|l|}{ Nemertea } \\
\hline Anopola & Cerebratulus lacteus & $\mathbf{x}$ & & & & Henry et al. 1998 \\
\hline \multicolumn{7}{|l|}{ Plathelminthes } \\
\hline \multirow[t]{3}{*}{ Turbellaria } & Dugesia japonica & $\mathbf{x}$ & & & & Sato et al. 2006 \\
\hline & Hoploplana inquilina & $\mathbf{x}$ & & & & Boyer et al. 1996 \\
\hline & Schmidtea mediterranea & $\mathbf{x}$ & & & & Wang 2007 \\
\hline
\end{tabular}

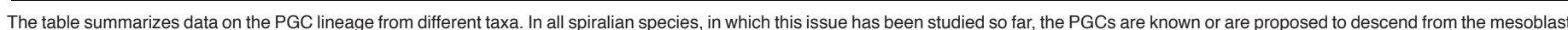

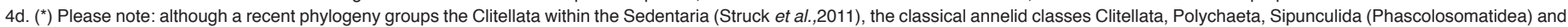

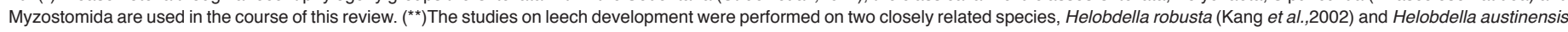

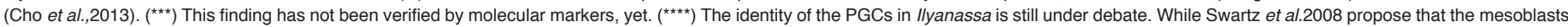

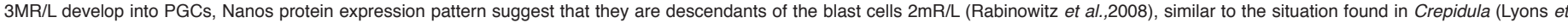
al.,2012). Blastomere nomenclature according to Lyons et al.,2012. Evidence for PGCs: $t=$ transcript (vasa, nanos or piwi), $\mathrm{p}=\mathrm{protein}$ (vasa or nanos), I=linage tracing, $\mathrm{h}=$ histology. 
unsolved. The broad occurrence of active PGC migration in other phyla however suggests that it constitutes a conserve trait in metazoan development (Extavour and Akam, 2003; Raz, 2004; Wylie 1999).

\section{From early to late: a heterochronic shift in germline segregation}

In the polychaetes Platynereis dumerilii and Salmacina dysteri well as in the mollusks Crepidula fornicata, the PGCs either constitute, or are derived from the first two pairs of blast cells $1 \mathrm{mR} / \mathrm{L}$ and 2mR/L (Lyons et al.,2012; Malaquin, 1925; Rebscher et al.,2012; and Fig. 3). A different situation is found in clitellates: in Helobdella spp., and Tubifex tubifex only the blast cells from the the $10^{\text {th }}$ or $16^{\text {th }}$ birth rank on, respectively, contribute to the germline (Cho et al.,2013; Kato et al.,2013; Kang et al.,2002 and Fig. 3). In Tubifex tubifex, the birth rank of the blast cell directly corresponds to the number of their future adult body segment. Thus the PGCs derived from $10 \mathrm{mR} / \mathrm{L}$ and $11 \mathrm{mR} / \mathrm{L}$ will later end up in the genital segments $X$ and $X I$, which harbor the female and male gonads of this hermaphroditic species. Additional vasa expressing blast cell descendants of unknown fate, therefore carefully called 'vasa-expressing cells' or 'presumptive PGCs', transiently occur in the adjacent segments VIII, IX, and XIII. However, these cells do not contribute to the germline and become undetectable in juveniles (Kato et al.,2013; Oyama et al.2007). In the leeches Helobdella austinensis and $H$. robusta, the first midbody segments are formed by the pair of blast cells $11 \mathrm{mR} / \mathrm{L}$ (= 'sm5'), while earlier blast cells contribute either to non-segmental structures $(1 \mathrm{mR} / \mathrm{L}$ to $6 \mathrm{mR} / \mathrm{L}=$ 'em1-6') or head structures $(7 \mathrm{mR} / \mathrm{L}$ to $10 \mathrm{mR} / \mathrm{L}=$ 'sm1-4'). Therefore, the descendants of the blast cells $16 \mathrm{mR} / \mathrm{L}(=$ 'sm10') that will produce the most anterior PGCs of the leech, are located in midbody segment M6 (Gline et al.,2011, Cho et al.2013 and Fig. 3). As in Tubifex tubifex, additional PGCs are specified transiently in Helobdella spp. in segments flanking the genital segments, i.e. in the midbody segments M14-M17 in H. robusta and in M14-M18 H. austinensis (Cho et al., 2013).

It is tempting to speculate, that the heterochronic shift observed in PGC formation in clitellates might be correlated with their successive, lineage-dependent segmentation process: in these species, the teloblasts located in the posterior growth zone continuously bud off bandlets of blast cells towards the anterior pole of the embryo. By lineage tracing experiments, it has been shown that blast cells of a given birth rank contribute to distinct segments in invariant patterns (Rivera and Weisblat, 2008; Weisblat and Shankland, 1985). Notably, in both Tubifex tubifex and Helobdell spp. the PGCs never cross the boundaries of the segments in which they are born (Cho et al.2013; Kato et al.,2013).Thus, by delaying PGC formation, this process seems to be synchronized with the formation of the future gonadal segments in clitellates.

\section{Germ cells, asexual reproduction, and regeneration}

Many spiralians are able to regenerate large parts of their body, including regions harboring the gonads. This raises the question of how these species maintain their fertility throughout regeneration or asexual reproduction. Regeneration of body regions initially lacking germ cells is best known from platyhelminths. The extraordinary regenerative capacities of these spiralians rely on multipotent stem cells called neoblasts distributed within the trunk mesenchyme (Rink, 2013; Wang Zaya et al.,2007). Recent investigations in the planarians Dugesia japonica and Schmidtea mediterranea have revealed that at least two different populations of neoblasts exist: while all neoblasts express the stem cell marker piwi, the germ cell marker nanos is restricted to a subpopulation of so called 'germline stem cells' (Handberg-Thorsager and Saló, 2007; Sato et al.,2006, Shibata et al.,2010 and Fig. 2E). In the trematode Schistosoma mansoni, which exhibits multiple generations of asexually propagating larval stages, clusters of so called 'germinal cells' exist which share high similarities in terms of morphology and gene expression pattern with planarian neoblasts: besides the piwi related piRNA interacting protein agonaute, three vasa-like transcripts are up-regulated in these

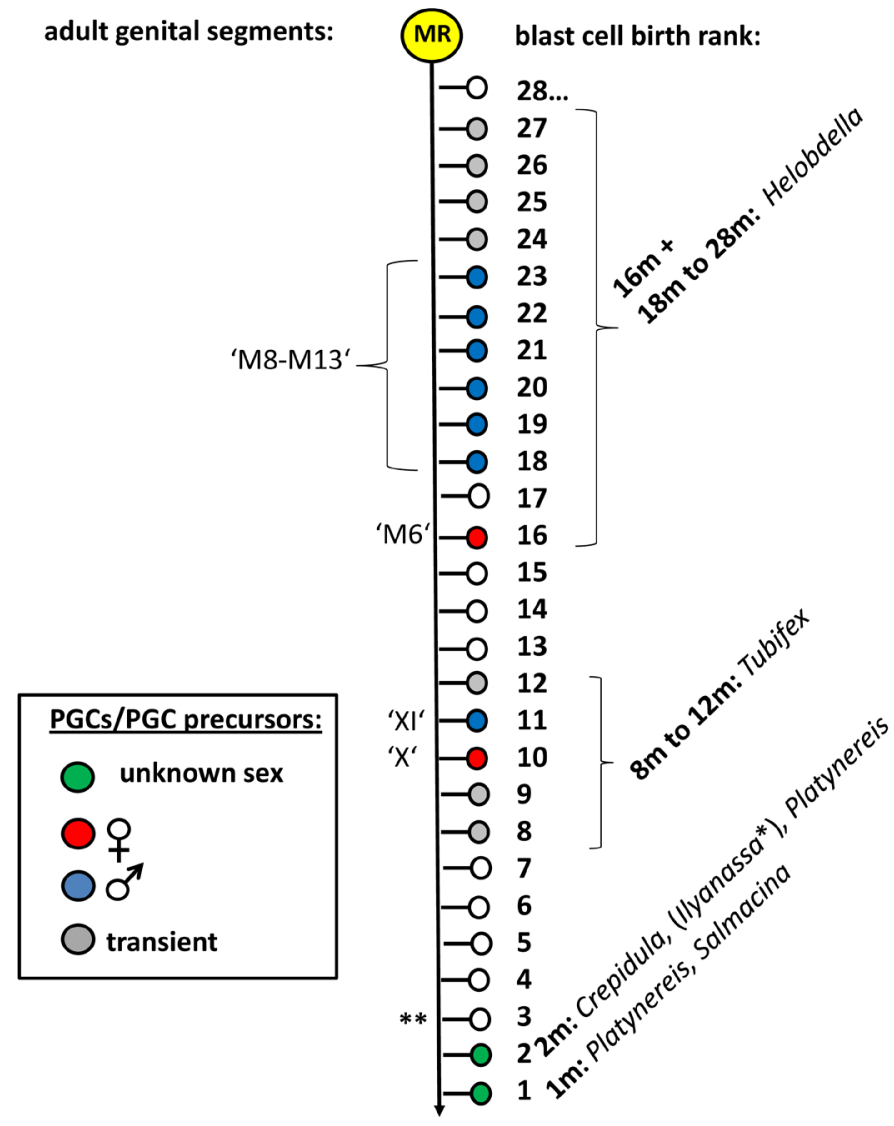

Fig. 3. Heterochronic shift in birth rank of primordial germ cells in clitellates. The mesoblasts MR and ML (yellow) sequentially produce small blast cells $(1 \mathrm{~m}, 2 \mathrm{~m}, 3 \mathrm{~m}$...). Only the right side of the embryo is shown. While the PGCs in mollusks and non-clitellate annelids are identical with or stem from the first two blast cells (1m and $2 m$, green), PGC formation occurs at much later stages in the clitellates Tubifex tubifex and Helobdella spp. For midbody segment nomenclature (M6, M8-M13) in Helobdella spp., refer to the text. Besides the definitive female (red) and male (blue) germ cell precursors, additional vasa, nanos and piwi positive cells (grey) occur transiently in the adjacent segments in clitellates. Blast cells contributing exclusively to somatic lineage are shown in white. (*) Blast cell birth rank for llyanassa PGC precursors as based on Rabinowitz et al.,2008. (**) Other authors suggested $3 M R / L$ as the PGCs in both llyanassa and the bivalve Sphaerium (Swartz et al.,2008; Woods et al. 1932). Modified after Cho et al.2013 and Kato et al. 2013. 
Fig. 4. Anterior location of primordial germ cells (PGCs) and caudal regeneration in Platynereis dumerilii. (A) The four PGCs (green) reside just anterior to the mesodermal posterior growth zone in the $48 \mathrm{hpf}$ trochophore larva. (B) At the end of larval development at day 4, the PGCs leave the growth zone and migrate anteriorly, until they reach a transient 'niche' in the neck region of the young worm (C). Loss of caudal segments by autotomy or amputation does not affect fertility from then on, since PGCs reside in a more anterior location. The worms are able to regenerate lost body segments as long as the head and at least 5 trunk segments remain (red dotted line, Hofmann, 1966). (D) At the onset of gametogenesis in juveniles > 20 segments, the PGCs start to proliferate, migrate posteriorly into the trunk mesoderm and form gonial clusters. (E) The gonial clusters enter the coelomic cavity, where they develop freely floating into gametes (here: oocytes).

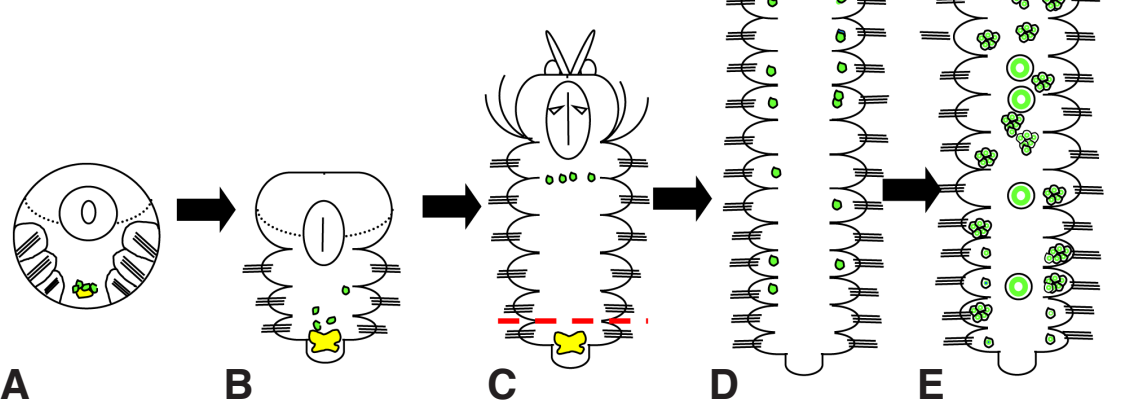

is threatened by a predator (Rebscher et al.,2007 and Fig. 4). Therefore, it comes as no surprise that Platynereis dumerilii can easily regenerate all but the first 5 of its trunk segments whilst still remaining fertile (Hofmann, 1966).

\section{The question of the PGC determinants: molecules, granules and germplasm}

In species in which the germline is established early in development by the inheritance of maternal determinants, maternal transcripts and proteins are assembled into ribonucleotide particles (RNPs) also called germinal granules, polar granules, or 'nuage' (Ewen-Campen et al.,2010; Wylie, 1999). In many spiralians, the germinal granules are compounds of a perinuclear yolk free cytoplasm formed during oogenesis. Upon fertilization, the yolk free cytoplasm - also called 'teloplasm' in the clitellates - is localized towards one (Fabioux et al.,2004; Rebscher et al.,2007) or both (Kang et al.,2002; Kato et al.,2013) poles of the fertilized egg in the course of ooplasmic segregation (Fig. 5, red box). During the following unequal cleavages, the yolk free cytoplasm is then preferentially segregated into the $D$-quadrant and later enriched in $4 d$, the paired mesoblasts $\mathrm{MR} / \mathrm{L}$, and the PGCs, respectively, suggesting an

cells. As in free living platyhelminths, only a subpopulation of these cells expresses nanos and exhibits a strongly prolonged cell cycle typical for PGCs in this parasite (Wang et al.,2013).

Within the annelids, the asexually reproducing clitellate Enchytraeus japonensis is able to regenerate fully functional gonads from any segment due to the life-long presence of so called 'germline stem cells' scattered throughout the trunk as a PGC reservoir (Sugio et al.,2008; Tadokoro et al.,2006). Similarly, in both Helobdella spp. and Tubifex tubifex, additional vasa/nanos/ piwi positive blast cell descendants are transiently detectable in non-genital segments (Oyama and Shimizu, 2007, Cho et al.2013 Kato et al.,2013, and Fig. 3). However, unlike in Enchytraeus japonensis, these cells have not been reported to contribute to the germline. Whether they are evolutionary remnants of a PGC reservoir as found in Enchytraeus japonensis, or rather constitute purely somatic stem cells, remains to be elucidated. So far nothing is known about regeneration of germ cells in mollusks or nemerteans.

Besides replacing lost germ cells by stem cells, a different strategy to cope with regeneration is found in the polychaete Platynereis dumeriili. Here, the PGCs migrate within a few days away from the posterior growth zone towards an anterior location, thus far away from the tail, which can autotomize when the worm

Fig. 5. Yolk free cytoplasm and segregation of putative germ cell determinants in spiralian embryos. Left: Yolk free cytoplasm (green) is localized around the nucleus (grey) in the unfertilized egg. It then segregates towards one or both poles of the fertilized egg and accumulates in the D quadrant in species, from which an accumulation of maternal germ cell determinants is known (red box). In other species (blue box), the germ cell markers analyzed so far exhibit a ubiquitous, nuclear or centrosomal localization during the first rounds of cleavage.

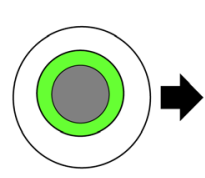

A

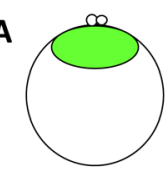

B

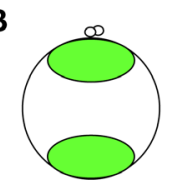

C
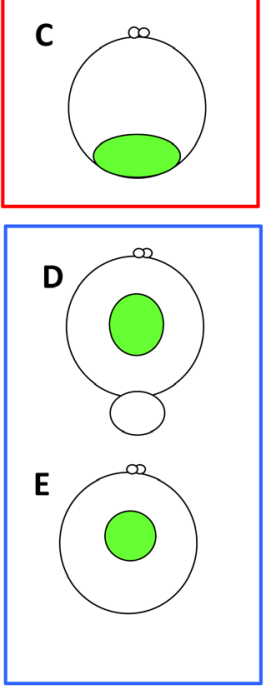

A: animal yolk free cytoplasm (Platynereis)

B: teloplasm

(Helobdella, Tubifex)

C: vegetal plasm

(Crassostrea, Sphaerium)
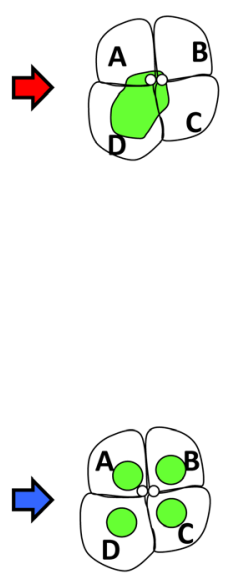

D: polar lobe

(Crepidula, llyanassa)

E: perinuclear/centrosomal (Capitella, Haliotis) 
early specification of the PGCs by inheritance of these cytoplasmic compounds in Crassostrea gigas, Helobdella spp., Platynereis dumerilii and Tubifex tubifex. In the gastropods Crepidula fornicata, Ilyanassa obsoleta, and Haliotis asinina, as well as in the polychaete Capitella telata, no asymmetric distribution of germ cell determinants in either fertilized eggs or early cleavage stages has been reported based on expression studies of vasa, nanos and piwi. Instead, these transcripts are found associated to the nuclei or centrosomes of all blastomeres of the cleaving embryos (Fig. $5 \mathrm{~B}$, blue box). A specific accumulation of vasa, nanos and piwi is only found later, when the mesoblasts MR/L form (Dill and Seaver, 2008; Giani et al.,2011; J. J. Henry et al.,2010; Swartz et al.,2008). However, it cannot be ruled out that future analyses at the protein level using specific antibodies will unravel the existence of asymmetrically segregating cytoplasmic determinants in these species.

In general, maternal proteins and transcripts have to be subject to a tight temporal and spatial regulation during development (Vasudevan et al.2006). In ecdysozoan and vertebrate species, Vasa is known to enhance the translation of nanos, cyclin $B$, and gurken in PGCs by its RNA unwinding capacity (Raz, 2000; Yajima and Wessel, 2011). Nanos in turn acts as a translational repressor, especially of genes related to somatic differentiation. Furthermore, it is involved in the establishment of transcriptional and mitotic quiescence in the PGCs (Asaoka-Taguchi et al.,1999; Leatherman and Jongens, 2003). The stability of maternal transcripts as well as their translation in the germline is additionally known to be regulated by miRNAs (Giraldez et al.,2006; Jin and Xie, 2006; Mishima et al.,2006). How the complex posttranscriptional networks operating in PGCs act to orchestrate PGC formation in spiralians still remains to be elucidated.

\section{Conclusions}

Their highly stereotypic cleavage pattern in conjunction with an increasing availability of molecular tools render spiralian embryos excellently suited to study the cellular and molecular events leading to the formation of the PGCs. Our knowledge on function and expression pattern of developmentally relevant genes in spiralians has greatly increased within the last decade. While an origin of PGCs from the mesoblast lineage seems to constitute a spiralian specific trait, the molecules involved in PGC specification such as Vasa, Nanos, and PIWI have turned out to be highly conserved between spiralians and other metazoans. Insights from spiralians as representatives of the superphylum Lophotrochozoa complement data obtained earlier from ecdysozoan and deuterostome species, and thus round up our understanding of the evolution of a distinct germline at the base of the animal kingdom.

\section{Acknowledgements}

Jonathan Henry, Emili Saló, and Takashi Shimizu for contributing unpublished pictures, Dr. Monika Hassel and Dr. Stephanie Bannister for critical reading of the manuscript. Part of this work was supported by DFG grant $R E-1726 / 4-1$ to $N R$.

\section{References}

ACKERMANN C F, DORRESTEIJN A W C, FISCHER A (2005). Clonal domains in postlarval Platynereis dumerilii (Annelida: Polychaeta). J Morphol 266: 252-258.

ASAOKA-TAGUCHI M, YAMADA M, NAKAMURA A, HANYU K, KOBAYASHI S (1999). Maternal Pumilio acts together with Nanos in germline development in
Drosophila embryos. Nat Cell Biol 1: 431-437.

BOYER B C, HENRY J J, MARTINDALE M Q (1998). The cell lineage of a polyclad turbellarian embryo reveals close similarity to coelomate spiralians. Dev Biol 204: 111-123.

CHO S-J, VALLÈS, Y, WEISBLAT D A (2014). Differential Expression of Conserved Germ Line Markers and Delayed Segregation of Male and Female Primordial Germ Cells in a Hermaphrodite, the Leech Helobdella. Mol Biol Evol 31: 1-14.

CONKLIN E G (1897). The embryology of Crepidula, a contribution to the cell lineage and early development of some marine gasteropods. J Morphol 13: 1-226.

DILL K K, SEAVER E C (2008). Vasa and nanos are coexpressed in somatic and germ line tissue from early embryonic cleavage stages through adulthood in the polychaete Capitella sp.I. Dev Genes Evol. 218: 453-463.

DONOUGHE S, NAKAMURA T, EWEN-CAMPEN B, GREEN II D A, HENDERSON L, EXTAVOUR C GM, (2014). BMP signaling is required for the generatin of primordial germ cells in an insect. Proc Nat Acad Sci 111: 4133-4138.

DORRESTEIJN A W C (1990). Quantitative analysis of cellular differentiation during early embryogenesis of Platynereis dumerilii. Roux's Arch Dev Biol 199: 14-30.

EWEN-CAMPEN B, SCHWAGER E E, EXTAVOUR C G M (2010). The molecular machinery of germ line specification. Mol Reprod Dev 77: 3-18.

EXTAVOUR C G M, AKAM M (2003). Mechanisms of germ cell specification across the metazoans: epigenesis and preformation. Development 130: 5869-5884.

EXTAVOUR C G M, PANG K, MATUS D Q, MARTINDALE M Q (2005). Vasa and nanos expression patterns in a sea anemone and the evolution of bilaterian germ cell specification mechanisms. Evol Dev 7: 201-215.

FISCHER A H L, ARENDT D (2013). Mesoteloblast-Like Mesodermal Stem Cells in the Polychaete Annelid Platynereis dumerilii (Nereididae). J Exp Zool Part B Mol Dev Evol 320: 94-104.

GAZAVE E, BÉHAGUE J, LAPLANE L, GUILLOU A, PRÉAU L, DEMILLY A, BALAVOINE G, VERVOORT M (2013). Posterior elongation in the annelid Platynereis dumerilii involves stem cells molecularly related to primordial germ cells. Dev Biol 382: 246-267.

GIANI V C, YAMAGUCHI E, BOYLE M J, SEAVER E C (2011). Somatic and germline expression of piwiduring development and regeneration in the marine polychaete annelid Capitella teleta. Evo Devo 2: 10

GIRALDEZ A J, MISHIMA Y, RIHEL J, GROCOCK R J, VAN DONGEN S, INOUE K, ENRIGHT A J, SCHIER A F (2006). Zebrafish MiR-430 Promotes Deadenylation and Clearance of Maternal mRNAs. Science 312: 75-79.

GLINE S E, NAKAMOTO A, CHO S-J, CHI C, WEISBLAT D A (2011). Lineage analysis of micromere $4 \mathrm{~d}$, a super-phylotypic cell for Lophotrochozoa, in the leech Helobdella and the sludgeworm Tubifex. Dev Biol 353: 120-133.

HANDBERG-THORSAGER M, SALÓ E (2007). The planarian nanos-like gene Smednos is expressed in germline and eye precursor cells during development and regeneration. Dev Genes Evol 217: 403-411.

HENRY J J, MARTINDALE, M Q (1998). Conservation of the spiralian developmental program: cell lineage of the nemertean, Cerebratulus lacteus. Dev Biol201:253-269.

HENRY J J, PERRY K J, FUKUI L, ALVI N (2010). Differential localization of mRNAs during early development in the mollusc, Crepidula fornicata. Integr. Comp Biol 50: 720-733.

HENRY J Q, COLLIN R, PERRY K J (2010). The Slipper Snail, Crepidula: An Emerging Lophotrochozoan Model System. Biol Bul. 218: 211-229.

HOFMANN D K (1966). Untersuchungen zur Regeneration des Hinterendes be Platynereis dumerilii (AUDOIN et Milne-Edwards) (Annelida, Polychaeta). Zool Jb Physiol 72: 374-430.

HUETTNER A F (1923). The origin of germ cells in Drosophila melanogaster. J Morphol 2: 385-422.

IKENISHI K, NAKAZATO S, OKUDA T (1986). Direct evidence for the presence of germ cell determinant in vegetal pole cytoplasm of Xenopus laevis and in a subcellular fraction of it. Dev Growth Diff 28: 563-568.

JIN Z, XIE T (2006). Germline Specification: Small Things Have a Big Role. Curr Biol 16: R966-R967.

JOHNSON A D, CROTHER B, WHITE M E, PATIENT R, BACHVAROVA R F, DRUM M, MASIT (2003). Regulative germ cell specification in axolotl embryos: a primitive trait conserved in the mammalian lineage. Phil Trans R Soc Lond B358, 1371-1379.

JULIANO C E, SWARTZ S Z, WESSEL G M (2010). A conserved germline multipotency program. Development 137: 4113-4126. 
KANG D, PILON M, WEISBLAT, D A (2002). Maternal and zygotic expression of a nanos-class gene in the leech Helobdella robusta: primordial germ cells arise from segmental mesoderm. Dev Biol 245: 28-41.

KATO Y, NAKAMOTO A, SHIOMI I, NAKAO H, SHIMIZU T (2013). Primordial germ cells in an oligochaete annelid are specified according to the birth rank order in the mesodermal teloblast lineage. Dev Biol 379: 246-257.

KRANZ A M, TOLLENARE A, NORRIS B J, DEGNAN B M, DEGNAN S M (2010). Identifying the germline in an equally cleaving mollusc: Vasaand Nanosexpression during embryonic and larval development of the vetigastropod Haliotis asinina. $J$ Exp Zool Part B Mol Dev Evol 314B: 267-279.

LAMBERT J D (2010). Developmental patterns in spiralian embryos. Curr Biol 20: R72-R77.

LASKO P (2011). Posttranscriptional regulation in Drosophila oocytes and early embryos. Wiley Interdiscip. Rev. RNA 2: 408-416.

LEATHERMAN J L, JONGENS TA (2003). Transcriptional silencing and translational control: key features of early germline development. Bioessays 25: 326-335.

LYONS D C, PERRY K J, LESOWAY M P, HENRY J Q (2012). Cleavage pattern and fate map of the mesentoblast, $4 \mathrm{~d}$, in the gastropod Crepidula: a hallmark of spiralian development. Evodevo 3: 21.

MCLAREN A (2003). Primordial germ cells in the mouse. Dev Biol 262: 1-15.

MAHOWALD A P (2001). Assembly of the Drosophila germ plasm. Int Rev Cytol 203: 187-213.

MISHIMA Y, GIRALDEZ A J, TAKEDA Y, FUJIWARA T, SAKAMOTO H., SCHIER A $F$, INOUE K (2006). Differential regulation of germline mRNAs in soma and germ cells by zebrafish miR-430. Curr Biol 16: 2135-2142.

MALAQUIN A (1925). La ségrégation, au cours de l'ontogenèse, de deux cellules sexuelles primordiales, souches de la lignée germinale, chez Salmacina dysteri (Huxley). C R Acad Sci (Paris) 180D: 324-327.

MOCHIZUKI K, NISHIMIYA-FUJISAWAC, FUJISAWAT (2001). Universal occurence of the vasa-related genes among metazoans and their germline expression in Hydra. Dev Genes Evo. 211: 299-308.

NIEUWKOOP P D, SATASURYA LA (1979). Primordial Germ Cells in the Chordates. Cambridge Univ. Press. Cambridge

OYAMA A, SHIMIZU T (2007). Transient occurence of vasa-expressing cells in nongenital segments during embryonic development in the oligochaete annelid Tubifex tubifex. Dev Genes Evol 217: 675-690.

PETER R, GSCHWENTNER R, SCHÜRMANN W, RIEGER R M, LADURNER P (2004). The significance of stem cells in free-living flatworms: one common source for all cells in the adult. J Appl Biomed 2: 35.

RABINOWITZJ S, CHAN XY, KINGSLEY E P, DUANY, LAMBERT JD (2008). Nanos is required in somatic blast cell lineages in the posterior of a mollusk embryo. Curr Biol 18: 331-336.

RAZ E (2000). The function and regulation of vasa-like genes in germ-cell development. Genome Biol 3: 1017.1-1017.6.

RAZ E (2002). Primordial germ cell development in zebrafish. Semin Cell Dev Biol 13: $489-495$.

RAZ E (2004). Guidance of primordial germ cell migration. Curr Opin Cell Biol 16: 169-173

REBSCHER N, LIDKEAK, ACKERMANN C F (2012). Hidden in the crowd: primordial germ cells and somatic stem cells in the mesodermal posterior growth zone of the polychaete Platynereis dumerillii are two distinct cell populations. Evol Dev 3: 9.

REBSCHER N, ZELADA-GoONZALÉZ F, BANISCH T U, RAIBLE F, ARENDT D (2007). Vasa unveils a common origin of germ cells and of somatic stem cells from the posterior growth zone in the polychaete Platynereis dumerilii. Dev Biol 306: 599-611.

RINK J C (2013). Stem cell systems and regeneration in planaria. Dev Genes Evol 223: $67-84$.

SATO K, SHIBATA N, ORII H, Amikura R, SAKURAI T, AGATA K, KOBAYASHI S, WATANABE $K$ (2006). Identification and origin of the germline stem cells as revealed by the expression of nanos -related gene in planarians. Dev Growth Differ 48: 615-628.

SCHNEIDER S Q, BOWERMAN B (2007). $\beta$-Catenin asymmetries after all animal/ vegetal-oriented cell divisions in Platynereis dumerilii embryos mediate binary cell-fate specification. Dev Cell 13: 73-86.

SEYDOUX G, BROWN R E (2006). Pathway to totipotency: lessons from germ cells.
Cell 127: 891-904

SEYDOUX G, FIRE A (1994). Soma-germline asymmetry in the distributions of embryonic RNAs in Caenorhabditis elegans. Development 120: 2823-2834.

SEYDOUX G, STROME S (1999). Launching the germline in Caenorhabditis elegans: regulation of gene expression in early germ cells. Development 126: 3275-3283.

SHIBATA N, ROUHANA L, AGATA K (2010). Cellular and molecular dissection of pluripotent adult somatic stem cells in planarians. Dev Growth Differ 52: 27-41.

SHINOMIYAA, TANAKA M, KOBAYASHI T, NAGAHAMA Y, HAMAGUCHI S (2000) The vasa-like gene, olvas, identifies the migration path of primordial germ cells during embryonic body formation stage in the medaka, Oryzias latipes. Dev Growth Differ 42: 317-326.

SHIRAE-KURABAYASHI M, MATSUDAK, NAKAMURAA (2011). Ci-Pem-1 localizes to the nucleus and represses somatic gene transcription in the germline of Ciona intestinalis embryos. Development 138: 2871-81.

SOLANA J (2013). Closing the circle of germline and stem cells: the Primordial Stem Cell hypothesis. EvoDevo 4:2

SPRADLING A, DRUMMOND-BARBOSA D, KAI T (2001). Stem cells find their niche. Nature 414: 98-104

STROME S, WOOD W B (1982). Immunofluorescence visualization of germ-linespecific cytoplasmic granules in embryos, larvae, and adults of Caenorhabditis elegans. Proc Natl Acad Sci USA 79: 1558-1562.

STRUCK T H, PAUL C, HILL N, HARTMANN S, HÖSEL C, KUBE M, LIEB B, MEYER A, TIEDEMANN R, PURSCHKE G, BLEIDORN C (2011). Phylogenomic analyses unravel annelid evolution. Nature 471: 95-98.

SUGIO M, TAKEUCHI K, KUTSUNA J, TADOKORO R, TAKAHASHI Y, YOSHIDANORO C, TOCHINAI S, (2008). Exploration of embryonic origins of germline stem cells and neoblasts in Enchytraeus japonensis (Oligochaeta, Annelida). Gene Expr Patterns 8: 227-236.

SUNANAGA T, INUBUSHI H, KAWAMURA K (2010). Piwi-expressing hemoblasts serve as germline stem cells during postembryonic germ cell specification in colonial ascidian, Botryllus primigenus. Dev Growth Differ 52: 603-614.

SWARTZ S Z, CHAN X Y, LAMBERT J D (2008). Localization of Vasa mRNA during early cleavage of the snail Ilyanassa. Dev Genes Evol 218: 107-113.

TADOKORO R, SUGIO M, KUTSUNA J, TOCHINAI S, TAKAHASHI Y (2006). Early Segregation of Germ and Somatic Lineages during Gonadal Regeneration in the Annelid Enchytraeus japonensis. Curr Biol 16: 1012-1017.

TAGUCHI A, TAK M, MOTOISHI M, OR H, MOCH M, WATANABE K (2012). Analysis of localization and reorganization of germ plasm in Xenopus transgenic line with fluorescence-labeled mitochondria. Dev Growth Differ 54: 767-776.

TSANG TE, KHOO P L, JAMIESON R V, ZHOU S X, ANG S L, BEHRINGER R, TAM P P (2001). The allocation and differentiation of mouse primordial germ cells. Int J Dev Biol. 45: 549-555

TSUNEKAWAN, NEITO M, SAKAI Y, NISHIDAT, NOCE T (2000). Isolation of chicken vasa homolog gene and tracing the origin of primordial germ cells. Development 127: $2741-2750$

VASUDEVAN S, SELI E, STEITS J A(2006). Metazoan oocyte and early embryo development program: a progression through translation regulatory cascades. Genes Dev 20:138-146.

WANG B, COLLINS J J, NEWMARK, P A (2013). Functional genomic characterization of neoblast-like stem cells in larval Schistosoma mansoni. Elife 2: e00768.

WANG Y, ZAYAS R M, GUO T, NEWMARK P A (2007). Nanos function is essentia for development and regeneration of planarian germ cells. Proc Natl Acad Sci USA 104: 5901-5906.

WEIGERT A, HELM C, HAUSEN H, ZARKZEWSKI A C, BLEIDORN C (2013) Expression pattern of Piwi-like genes in adult Myzostoma cirriferum (Annelida). Dev Genes Evol 223: 329-334.

WEISBLAT D A, SHANKLAND M (1985). Cell lineage and segmentation in the leech Phil Trans $R$ Soc Lond B 312: 39-56.

WILSON E B (1892). The cell-lineage of Nereis. A contribution to the cytogeny of the annelid body. J Morphol 6: 361-480.

WOODS F H (1931). History of the germ cells in Sphaerium striatinum (Lam). $J$ Morphol 51: 545-595.

WU H-R, CHEN Y-T, SU Y-H, LUO Y-J, HOLLAND L Z, YU J K (2011). Asymmetric localization of germline markers Vasa and Nanos during early development in the amphioxus Branchiostoma floridae. Dev Biol 353: 147-159. 
WYLIE C (1999). Germ cells. Cell 96: 165-174.

YAJIMA M, WESSEL G M (2011a). Small micromeres contribute to the germline in the sea urchin. Development 138: 237-243.

YAJIMA M, WESSEL G M (2011b). The multiple hats of Vasa: Its functions in the germline and in cell cycle progression. Mol Reprod Dev 78: 861-867.
YING X-P, DAHMS H-U, LIU X-M, WU H-X, ZHANG Y-P, CHEN C, ZHOU Z-M, ZENG G-Q, ZHOU K, YANG W-X (2009). Development of germ cells and reproductive biology in the sipunculid Phascolosoma esculenta. Aquac Res 40: 305-314.

YING Y, QI X, ZHAO G Q (2001). Induction of primordial germ cells from murine epiblasts by synergistic action of BMP4 and BMP8 signaling pathways. Proc Natl Acad Sci USA 98: 7858-7862.

\section{Further Related Reading, published previously in the Int. J. Dev. Biol.}

Brachyury, Tbx2/3 and sall expression during embryogenesis of the indirectly developing polychaete Hydroides elegans Cesar Arenas-Mena

Int. J. Dev. Biol. (2013) 57: 73-83

http://dx.doi.org/10.1387/ijdb.120056ca

Planarian embryology in the era of comparative developmental biology

José M. Martín-Durán, Francisco Monjo and Rafael Romero

Int. J. Dev. Biol. (2012) 56: 39-48

http://dx.doi.org/10.1387/ijdb.113442jm

Cell lineage analysis of pattern formation in the Tubifex embryo. II. Segmentation in the ectoderm

A Nakamoto, A Arai and T Shimizu

Int. J. Dev. Biol. (2000) 44: 797-805

http://dx.doi.org/10.1387/ijdb.11128574

Cell lineage analysis of pattern formation in the Tubifex embryo. I. Segmentation in the mesoderm

A Goto, K Kitamura and T Shimizu

Int. J. Dev. Biol. (1999) 43: 317-327

http://dx.doi.org/10.1387/ijdb.10470648

Role of stem cell proteins and microRNAs in embryogenesis and germ cell cancer Ronak Eini, Lambert C. J. Dorssers and Leendert H. J. Looijenga*

Int. J. Dev. Biol. (2013) 57: 319-332

http://dx.doi.org/10.1387/ijdb.130020re

The Dr-nanos gene is essential for germ cell specification in the planarian Dugesia ryukyuensis

Haruka Nakagawa, Hirotsugu Ishizu, Ayako Chinone, Kazuya Kobayashi and Midori Matsumoto* Int. J. Dev. Biol. (2012) 56: 165-171

http://dx.doi.org/10.1387/ijdb.113433hn

5 yr ISI Impact Factor $(2011)=2.959$

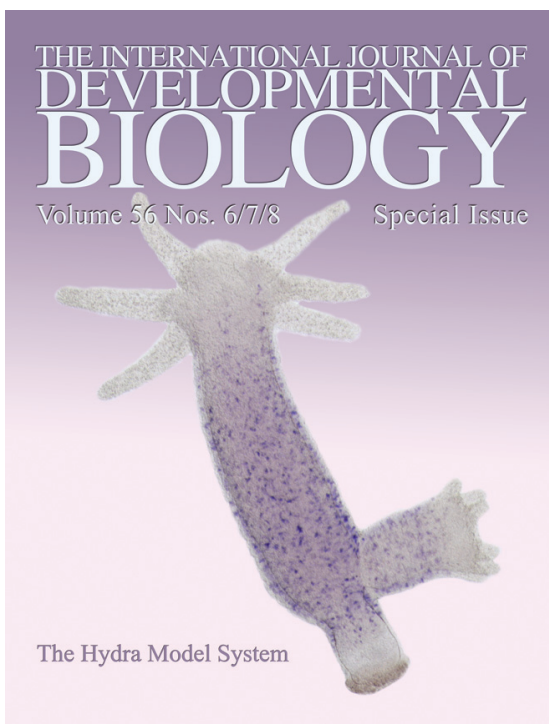

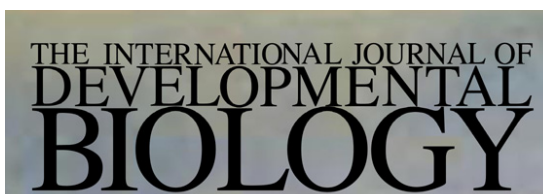

Volume 47 Nos. $7 / 8$ Special Issue

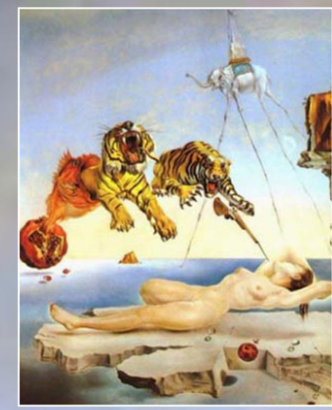

Evolution \& Development
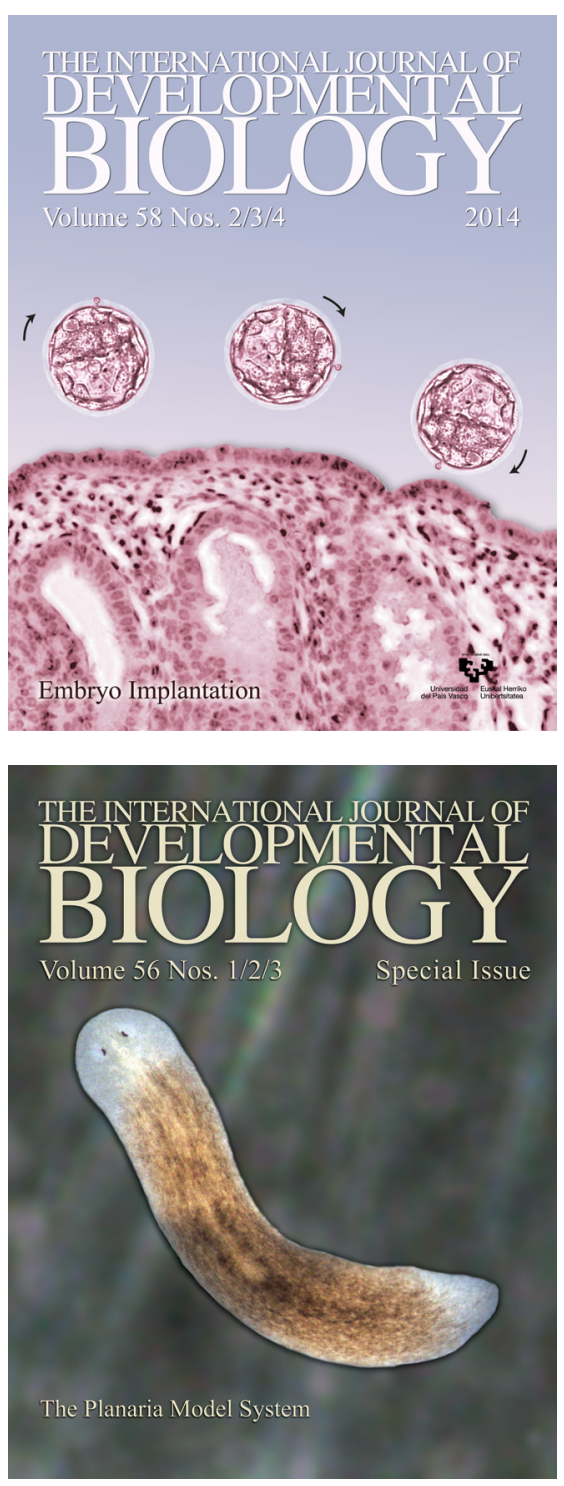